\title{
Education as a key to promoting insects as food
}

\author{
B.A. Rumpold ${ }^{1 *}$ iD and A. van Huis ${ }^{2}$ iD \\ ${ }^{1}$ Department of Education for Sustainable Nutrition and Food Science, Technische Universität Berlin, Marchstr. 23, 10587 \\ Berlin, Germany; ${ }^{2}$ Laboratory of Entomology, Wageningen University E Research, P.O. Box 16, 6700 AA Wageningen, the \\ Netherlands; rumpold@tu-berlin.de
}

(c) 2021 Wageningen Academic Publishers

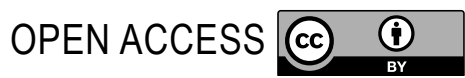

\section{EDITORIAL}

\begin{abstract}
Children in tropical countries have always eaten insects but are now often discouraged from doing so. Recently, the idea of the consumption of insects has been re-introduced as an answer to malnutrition since edible insects are a potential alternative and sustainable protein and food source. However, in countries where the consumption of insects is not traditional, there is a lack of acceptance as well as skills when it comes to preparing a meal with insects. Examples of experiments from different parts of the world are given, where children in schools are educated about the nutritional and environmental benefits of eating insects. In general, after the experience, children are more positive about the idea of eating insects. It is stipulated that insects as food could be a very good entry point for the discussion about our future food supply. Furthermore, with the increasing commercial production of edible insects, there is an increasing demand for skilled workers in the insect production industry. Essential to the promotion of insect consumption are the development of curricula and educational materials for vocational education, training of insect farmers, and general education in primary and secondary schools as well as tertiary education.
\end{abstract}

\section{Introduction}

There are a number of articles dealing with the nutritional benefits of providing an insect meal to children in developing nations. This was often to improve nutritional quality (Rhynchophorus ferrugineus in Indonesia; Nirmala et al., 2017), provide protein (different edible insect species in Kenya; Kipkoech et al., 2020), prevent undernutrition (crickets in Cambodia; Menasria et al., 2018; Walia et al., 2018) and anaemia or stunting (caterpillars in the Democratic Republic of Congo; Bauserman et al., 2015). In Kenya the acceptability was evaluated by incorporating the insect ingredient in familiar products like biscuits (Homann et al., 2017) or porridge (Kinyuru et al., 2021; Konyole et al., 2012). Is this revisiting the past? In Mali, according to Looy et al. (2014) children have foraged for grasshoppers for generations. However, now parents discourage their children from eating grasshoppers for fear that the grasshoppers are contaminated with chemicals. Another reason could be the global reach of Western culture, which is often strongly and erroneously biased against insect consumption. This means that a wholesome, complete, locally available, and free protein source has been removed from the diet. This may have considerably increased the risk of protein-energy malnutrition and its associated negative physical and mental consequences, especially for developing children (Looy et al., 2014).

Would education in schools encourage children to be more willing to incorporate insects into their diet? More than two decades ago, Matthews et al. (1997) recommended using insects in curricula, considering their numbers, diversity, adaptability, and evolutionary success. Other reasons for including insects as excellent teaching models are that they are easy to maintain, easy to handle, and widely available. The authors mentioned the study of the behaviour of crickets and mealworms, and their usefulness as feed for animals. At the time of that publication, the idea of using them as human food had not yet received much attention. However, nowadays, students from secondary schools and universities experiment with insects as ingredients of food products (e.g. https://www.youtube.com/watch?v=05caVyP0P0U).

\section{Importance of education}

When the late former secretary general of the United Nations, Kofi Annan, was interviewed for a cookbook (Van Huis et al., 2014: 6-7) about the eating of insects, he said: 
... It is a question of education. If, today, you raise the possibility of eating insects in the Western world, the reaction is often one of disgust, except among people who have travelled and been around. Yet, when you look at the facts - for example, that the human population is growing rapidly, with the expansion of the middle class and the pressures on the traditional protein sources, beef and poultry meat - we will not be able to sustain the demand. Particularly when you consider the imprint of cattle and other livestock on the environment, you are better off with insects. Insects have a very good conversion rate from feed to meat. There is no way that we can sustain conventional livestock production environmentally if we want to meet the needs of the growing human population.

Western people in general have a negative attitude towards invertebrates, and according to Looy et al. (2014) insects as food are a threat to our psychological and cultural identity. Moreover, DeFoliart (1999) indicated the adverse impact of this western bias. However, there is an increasing realisation that insects as food and feed may be a viable alternative to the protein obtained from common livestock species. This interest relates to the environmental, nutritional and health benefits of this mini-livestock, while the insect product seems safe to eat. Insects as food and feed could be addressed in formal education as one of the ingredients in our future food supply, corresponding to Sustainable Development Goal (SDG) 4 ‘Quality education' and SDG 12 'Responsible consumption and production'. Several studies addressing the issue will be summarised below. Three points of contact for education on insects as food are introduced:

- Education about farming, foraging and preparing insects as a traditional food source in countries where there has been a tradition of consuming insects. In case of foraging, this should also include sustainable harvesting practices for the conservation of (endangered) insect species.

- Education about preparation and consumption of commercially available edible insects in countries where there is no tradition of consuming insects.

- Vocational education and training (VET) of personnel for the insect production industry such as insect farmers, food producers, cooks and related vocations. This should also include the education of instructors and vocational teachers.

\section{Educational examples of insects as a traditional food}

Due to urbanisation and westernisation, the consumption of insects has decreased in countries where the collection and consumption of insects used to be a tradition (Van Huis et al., 2013: 38). Recently, a turnaround has occurred and insects are being re-introduced to combat malnutrition (Van
Huis et al., 2013: 80). In addition to awareness-raising and the conservation of traditional competences, edible insects could be used in multidisciplinary educational settings in the context of future food supply and sustainability.

Dzerefos and de Sousa (2020) recommend incorporating indigenous knowledge of insects as food and feed in curricula in African schools. Shin et al. (2018) for example, proposed inviting insect harvesters to schools as guest speakers to share their oral tradition, and specialised field training with younger generations. Such a presentation could be followed by a science project to rear insects. Dzerefos and de Sousa (2020) made a colourful comic for children in South Africa about an edible stinkbug, giving information about the insects, instructions on how to make an origami stinkbug, how to remove chemicals to render them palatable, and a crossword puzzle.

In South Korea, the Korean Edible Insect Laboratory (KEIL) increased the value of the edible insect market from USD 143 million in 2011 to USD 259 million in 2015 (Shin et al., 2018). KEIL implemented a wide range of educational programmes for young South Koreans, as well as providing government funds to support edible insect sensory education for children and families.

In mountainous central Japan people hunt and eat the wasp 'hebo', and semi-cultivate Vespula spp. as a hobby (Nonaka and Yanagihara, 2019). However, younger generations have not taken up the hobby or have moved to urban areas in search of jobs, leaving seniors as the only hebo hunters. An agricultural high school took up the challenge and created a hebo club, where pupils learn from elders to find, collect, house, and rear the edible wasps. In this way the hebo culture in this part of Japan is maintained and preserved.

\section{Educational examples of insects as a novel food}

Among Westerners, the acceptance of edible insects is still low. Lack of tradition and familiarity, legal restrictions and resulting low availability, food neophobia, and disgust are key factors impeding the entry of edible insects in Western markets (Hartmann and Siegrist, 2016). Therefore, promotion of willingness-to-eat and positive experiences are just as important as knowledge on the beneficial aspects of edible insects and their preparation. Again, edible insects could be used in multidisciplinary educational settings in the context of future food supply and sustainability.

Nyberg et al. (2021) conducted focus group discussions in Sweden with public pre-school children of 4 and 5 years old, and the main conclusion was that children's emotions range from curiosity to fear. The tension between neophobia and neophilia is well known; however, by taking the starting point of young children's curiosity and imagination about 
insects as food, not only knowledge but also interest in insects as food might increase.

Tranter (2013) conducted a survey about the eating of insects among 8-10 year-old children in schools of an English town. The best way of introducing insects as food was to stress the health and environmental benefits. They did not serve the insects in their whole form but concealed them in cereal bars and chocolates. According to Tranter (2013) edible insects could be the bait in school curricula to address current food consumption and production patterns that are considered both unsustainable and unhealthy. Targeting children inevitably means addressing their parents. Would educating children about the eating of insects influence their parents' food habits? Lawson et al. (2019) looked at intergenerational learning. Children in the treatment group went through a curriculum about climate change, while the control group did not. Compared to the control group, children in the treatment group and their parents showed greater increases in climate change concern and this was more pronounced in groups that are typically most resistant to climate change communication, daughters being more effective than sons. The importance of the social context was also mentioned by Larson and Story (2009): parents and other family food preparers play central roles in shaping the dietary habits of household members. In the home, adults provide foods to children, and model and teach what, when, and how to eat. Beyond the family unit, the social context are co-workers, peers, and close friends.

Children can be encouraged to use all their senses while they create, investigate and explore. This is called sensory education or sensory learning. In Finland this was done using a $1 \frac{1}{2}$ year learning programme for 8-12 year-old children by encouraging them to eat foods they had never eaten before (Mustonen and Tuorila, 2010). Children in the education groups had tasted a larger number of unfamiliar foods than at the baseline, while no change was seen in the control group. The effect of decreased food neophobia was greatest with the most intense education, in particular in the younger children.

Chow et al. (2021) examined the strategy to reduce children's natural neophobic reactions by cooking the insects. Grasshopper and mealworm were incorporated into a traditional Danish snack (oatmeal balls). While the cooking exercise did not influence acceptance, the first tasting compared more favourably to the second and the mealworm version was preferred over the grasshopper one.

Dupont and Fiebelkorn (2020) examined the willingness of children and adolescents in Germany to consume insects and found that older respondents showed a greater willingness to consume insect burgers. This may be in accordance with $\mathrm{Nu}$ et al. (1996) who looked at French adolescents (10-20 year old) and showed that young people try more foreign food with increasing age, with the turning point being puberty. The way the insect product is offered (such as burger) is a strong predictor for the willingness to consume, stressing the importance of marketing and education (Dupont and Fiebelkorn, 2020).

When wanting to create a change in eating habits to more healthy and sustainable food items, Jones and Beynon (2020) argue that we need to consider the practice of how to achieve this goal. They explored introducing insects as food and inverting the negative social and cultural pre-conceptions among young people (aged 6-14 years) in schools in Wales. They included non-visible insect ingredients in a familiar dish by using a Bakhtin (1984) 'carnivalesque' approach (subverting and liberating the assumptions of the dominant style or atmosphere through humour and chaos). From a quarter before the workshop to more than half of the pupils after the workshop said they would choose products containing insects for school lunch. It showed the potential of forging new relationships between young people and sustainable, healthy food.

Capturing children's imagination about insects (as food) can also be done with exhibitions. The Natural History Museum in London achieved this with their portable exhibition, entitled 'Eating Creepy Crawlies' (Fairman, 2010). The exhibition focuses on a range of insects as food throughout the world. It provides details about the insects and their life cycles, and how they taste in comparison to familiar domestic foods. The exhibition teaches the children that insects may be small but certainly not insignificant: we need them, and they do not need us.

Cicatiello et al. (2016) explored the attitude of Italian consumers towards the consumption of insects. Although they found little data on the socio-demographic profile of potential Western edible insect consumers, they concluded that higher education was an important factor. This may be linked to increased awareness of nutritional and environmental benefits of edible insects (Reverberi, 2021).

With the goal of creating positive experiences with insects in food, of highlighting the benefits of insect production and reducing the novelty of edible insects, Petersen et al. (2020) developed an experiential learning lesson plan for university students that included a tasting. They observed that a positive perception of insects as food increased with increased exposure to consumption of insects and increased knowledge.

\section{Examples for vocational education and training}

With an expected increasing demand in insects as food and an up-scaling of insect production soon, the demand for skilled personnel in the insect production industry will 
increase. This includes e.g. insect farmers, food producers, cooks and related vocations. Appropriate curricula and educational materials need to be developed in cooperation with the insect production industry. In addition, instructors and vocational teachers also need to be educated. A formal education about insect production, processing and preparation within VET could concomitantly also promote edible insects. For example, knowledge about taste and preparation as well as cooking skills not only enable a cook to offer tasty insect-containing dishes but also have the potential to transform insects into common ingredients for fine-dining as well as casual dining.

Halloran and Flore (2018) evaluated the opinions of aspiring chefs in a Basque culinary centre concerning the use of edible insects in gastronomy. While education and proper training increased the aspiring chefs' willingness to experiment with different insect species in the kitchen, the authors observed several practical and cultural barriers to be overcome.

\section{Conclusions}

The current food systems contribute to climate change, environmental destruction, overexploitation of natural resources and pollution of air, water and soils (Dury et al., 2019). In the future, our children will have to live with the consequences and will suffer most from it. Therefore, educating children about sustainable alternatives seems to be the logical path to equip them with the knowledge, skills and competences needed for a transformation towards sustainable food production and consumption. Insects as food may be an excellent entry point in showing that sustainable alternatives to meat are available. In addition, edible insects represent an additional nutrient and energy source and might relieve malnutrition. Educational topics include the promotion and preservation of traditional yet sustainable consumption patterns, the promotion of insect consumption in regions where insects are not traditionally consumed, and the education of skilled insect farmers and insect food producers. Naturally, this implicates education for sustainable development in compliance with SDG 4 'Quality education' and SDG 12 'Responsible consumption and production'.

\section{References}

Bakhtin, M., 1984. Rabelais and his world. Indiana University Press, Bloomington, USA.

Bauserman, M., Lokangaka, A., Gado, J., Close, K., Wallace, D., Kodondi, K.-K., Tshefu, A. and Bose, C., 2015. A cluster-randomized trial determining the efficacy of caterpillar cereal as a locally available and sustainable complementary food to prevent stunting and anaemia. Public Health Nutrition 18: 1785-1792. https://doi. org/10.1017/S1368980014003334
Chow, C.-Y., Riantiningtyas, R.R., Sørensen, H. and Bom Frøst, M., 2021. School children cooking and eating insects as part of a teaching program - Effects of cooking, insect type, tasting order and food neophobia on hedonic response. Food Quality and Preference 87: 104027. https://doi.org/10.1016/j.foodqual.2020.104027

Cicatiello, C., Rosa, B.D., Franco, S. and Lacetera, N., 2016. Consumer approach to insects as food: barriers and potential for consumption in Italy. British Food Journal 118: 2271-2286. https://doi.org/10.1108/ BFJ-01-2016-0015

DeFoliart, G.R., 1999. Insects as food: why the western attitude is important. Annual Review of Entomology 44: 21-50.

Dupont, J. and Fiebelkorn, F., 2020. Attitudes and acceptance of young people toward the consumption of insects and cultured meat in Germany. Food Quality and Preference 85: 103983. https://doi. org/10.1016/j.foodqual.2020.103983

Dury, S., Bendjebbar, P., Hainzelin, E., Giordano, T. and Bricas, N., 2019. Food systems at risk. New trends and challenges. FAO, Rome, Italy, 132 pp. https://doi.org/10.19182/agritrop/00080

Dzerefos, C.M. and de Sousa, L.O., 2020. Insect protein squashes preconceived ideas of entomophagy, sparking critical reflection on sustainability and educational resources. The Geography Teacher 17: 117-124. https://doi.org/10.1080/19338341.2020.1796740

Fairman, R.J., 2010. Instigating an education in insects: the eating creepy crawlies' exhibition. Antenna 34: 169-170.

Halloran, A. and Flore, R., 2018. A new world of ingredients: aspiring chefs' opinions on insects in gastronomy. In: Halloran, A., Flore, R., Vantomme, P. and Roos, N. (eds.) Edible insects in sustainable food systems. Springer International Publishing, Cham, Switzerland, pp. 129-137. https://doi.org/10.1007/978-3-319-74011-9_8

Hartmann, C. and Siegrist, M., 2016. Insects as food: perception and acceptance. Findings from current research. Ernährungsumschau International 64: 44-50. https://doi.org/10.4455/eu.2017.010

Homann, A.M., Ayieko, M.A., Konyole, S.O. and Roos, N., 2017. Acceptability of biscuits containing 10\% cricket (Acheta domesticus) compared to milk biscuits among 5-10-year-old Kenyan schoolchildren. Journal of Insects as Food and Feed 3: 95-103. https://doi.org/10.3920/jiff2016.0054

Jones, V. and Beynon, S., 2020. Edible insects: applying Bakhtin's carnivalesque to understand how education practices can help transform young people's eating habits. Children's Geographies 19: 13-23. https://doi.org/10.1080/14733285.2020.1718608

Kinyuru, J., Kipkoech, C., Imathiu, S., Konyole, S. and Roos, N., 2021. Acceptability of cereal-cricket porridge compared to cereal and cereal-milk- porridges among caregivers and nursery school children in Uasin Gishu, Kenya. International Journal of Tropical Insect Science 41: 2007-2013. https://doi.org/10.1007/s42690-020-00388-1

Kipkoech, C., Yugi, A., Mbembe, M., Kosgei, P., Pricillah Ngetich, Wesonga, J. and Dibaba, A., 2020. Utilizing edible insects as a protein source in children under 2 years: increasing animal protein intake to improve nutrition. https://www.researchgate. net/publication/348351250 
Konyole, S.O., Kinyuru, J.N., Owuor, B.O., Kenji, G.M., Onyango, C.A., Estambale, B.B., Friis, H., Roos, N. and Owino, V.O., 2012. Acceptability of amaranth grain-based nutritious complementary foods with dagaa fish (Rastrineobola argentea) and edible termites (Macrotermes subhylanus) compared to corn soy blend plus among young children/mothers dyads in Western Kenya. Journal of Food Research 1: 111-120. https://doi.org/10.5539/jfr.v1n3p111

Larson, N. and Story, M., 2009. A review of environmental influences on food choices. Annals of Behavioral Medicine 38: 56-73. https:// doi.org/10.1007/s12160-009-9120-9

Lawson, D.F., Stevenson, K.T., Peterson, M.N., Carrier, S.J., L. Strnad, R. and Seekamp, E., 2019. Children can foster climate change concern among their parents. Nature Climate Change 9: 458-462. https:// doi.org/10.1038/s41558-019-0463-3

Looy, H., Dunkel, F.V. and Wood, J.R., 2014. How then shall we eat? Insect-eating attitudes and sustainable foodways. Agriculture and Human Values 31: 131-141. https://doi.org/10.1007/s10460-0139450-x

Matthews, R.W., Flage, L.R. and Matthews, J.R., 1997. Insects as teaching tools in primary and secondary education. Annual Review of Entomology 42: 269-289.

Menasria, L., Blaney, S., Main, B., Vong, L., Hun, V., Raminashvili, D., Chhea, C., Chiasson, L. and Leblanc, C., 2018. Mitigated impact of provision of local foods combined with nutrition education and counseling on young child nutritional status in Cambodia. Nutrients 10: 1450. https://doi.org/10.3390/nu10101450

Mustonen, S. and Tuorila, H., 2010. Sensory education decreases food neophobia score and encourages trying unfamiliar foods in 8-12-year-old children. Food Quality and Preference 21: 353-360. https://doi.org/10.1016/j.foodqual.2009.09.001

Nirmala, I.R., Trees, Suwarni and Pramono, M.S., 2017. Sago worms as a nutritious traditional and alternative food for rural children in Southeast Sulawesi, Indonesia. Asia Pacific Journal of Clinical Nutrition 26 (Suppl.1): 40-49.

Nonaka, K. and Yanagihara, H., 2019. Reviving the consumption of insects in Japan: A promising case of hebo (Vespula spp., wasps) by high school club activities. Journal of Insects as Food and Feed 6: 45-50. https://doi.org/10.3920/JIFF2019.0005
Nu, C.T., MacLeod, P. and Barthelemy, J., 1996. Effects of age and gender on adolescents' food habits and preferences. Food Quality and Preference 7: 251-262. https://doi.org/10.1016/S09503293(96)00023-7

Nyberg, M., Olsson, V. and Wendin, K., 2021. 'Would you like to eat an insect?' - Children's perceptions of and thoughts about eating insects. International Journal of Consumer Studies 5: 248-258. https://doi.org/10.1111/IJCS.12616

Petersen, M., Olson, O. and Rao, S., 2020. University student perspectives of entomophagy: positive attitudes lead to observability and education opportunities. Journal of Insect Science 20: 30. https://doi.org/10.1093/jisesa/ieaa120

Reverberi, M., 2021. The new packaged food products containing insects as an ingredient. Journal of Insects as Food and Feed 7: 901-908. https://doi.org/0.3920/JIFF2020.0111

Shin, J.T., Baker, M.A. and Kim,Y.W., 2018. Edible insects uses in South Korean gastronomy: 'Korean edible insect laboratory' case study. In: Halloran, A., Flore, R., Vantomme, P. and Roos, N. (eds.) Edible insects in sustainable food systems. Springer International Publishing, Cham, Switzerland, pp. 147-159. https:// doi.org/10.1007/978-3-319-74011-9_10

Tranter, H., 2013. Insects creeping into English diets: introducing entomophagy to school children in a provincial town. University of East Anglia, School of Biological Sciences, Norwich, UK. https:// foodsecurityfoodjustice.files.wordpress.com/2017/01/3fff6htranter_msc2013.pdf

Van Huis, A., Van Gurp, H. and Dicke, M., 2014. The insect cookbook: food for a sustainable planet. Columbia University Press, New York, NY, USA.

Van Huis, A., Van Itterbeeck, J., Klunder, H., Mertens, E., Halloran, A., Muir, G. and Vantomme, P., 2013. Edible insects: future prospects for food and feed security. FAO Forestry Paper no. 171. Food and Agriculture Organization of the United Nations (FAO), Rome, Italy, 187 pp. Available at: http://www.fao.org/docrep/018/i3253e/ i3253e.pdf.

Walia, K., Kapoor, A. and Farber, J.M., 2018. Qualitative risk assessment of cricket powder to be used to treat undernutrition in infants and children in Cambodia. Food Control 92: 169-182. https://doi. org/10.1016/j.foodcont.2018.04.047 
